\title{
Broadband Policy in the Light of the Dutch Experience with Telecommunications Liberalization
}





\title{
Broadband Policy in the Light of the Dutch Experience with Telecommunications Liberalization
}

\author{
Paul W.J. de Bijl*
}

March, 2011

\footnotetext{
* Head of Dept. Competition and Regulation, CPB Netherlands Bureau for Economic Policy Analysis, Den Haag, Netherlands; extramural fellow of TILEC, Tilburg University; fellow of ENCORE. I am grateful to seminar participants at the workshop Effective Competition (Justus-Liebig-University, Giessen), the Economics of Infrastructures section at Delft University of Technology, and the experts workshop The Broadband Act of 2011: Designing A Communications Act for the 21 st Century, Washington DC, for helpful discussions. I also wish to thank the editor and two anonymous reviewers for their comments and suggestions.
} 


\begin{abstract}
More than a decade has passed since the liberalization of telecommunications in the Netherlands. Nevertheless, the regulator is still mandating access to local access networks, and the incumbent and cable operators have been dragging their feet on upgrading their networks to fiber-based next generation networks. Is the gradual introduction of facilities-based competition, by fine-tuning access regulation, working as intended? What can one learn from the Dutch experience? As scale economies are persistent and broadband networks are becoming an integral part of our critical infrastructures, it is important to reassess the role of the government, on issues ranging from network neutrality to broadband penetration, universal service, and security. The outcome of such an assessment could be incongruent with the blueprint of competition held on to by policymakers and regulators.
\end{abstract}

Keywords: regulation, telecommunications, government policy w.r.t. technological change. JEL-codes: L51 (Economics of Regulation), L96 (Telecommunications), L98 (Government Policy), O33 (Technological Change: Choices and Consequences; Diffusion Processes)

\begin{abstract}
Dutch
Meer dan een decennium is inmiddels verstreken sinds de liberalisering van telecommunicatie in Nederland. Toch is er nog steeds toegangsregulering tot lokale aansluitnetwerken en gaat de verglazing van netwerken door incumbent en kabelbedrijven niet erg hard. Werkt de geleidelijke invoering van infrastructuurconcurrentie, op basis van gedetailleerde toegangsregulering tot netwerken, als beoogd? Wat kan men leren van de Nederlandse ervaring? Nu schaalvoordelen persistent zijn gebleken en breedbandnetwerken een integraal onderdeel van onze kritieke infrastructuur zijn geworden, is het belangrijk om de rol van de overheid opnieuw te bezien, met betrekking tot onderwerpen variërend van netneutraliteit tot breedbandpenetratie, universele diensten en veiligheid. De uitkomst van een dergelijke beoordeling wijkt mogelijk af van de blauwdruk van concurrentie die gangbaar is bij beleidsmakers en toezichthouders.
\end{abstract}

Trefwoorden: regulering, telecommunicatie, overheidsbeleid m.b.t. technologische verandering. 


\section{Introduction}

Has the liberalization of the telecommunications market in the Netherlands been successful? At first sight, the answer seems to be affirmative, but nevertheless, it is not easy to answer this question, because the telecommunications market no longer exists as a separate sector. Telecommunications - or better, electronic communications - has been transformed by the Internet. The sector is now closely connected to the media sector. This development is known as convergence between telecommunications, the Internet and media. The Internet protocol (IP) - the method by which digitized data is divided into packets and then sent from one computer to another - has permeated networks, services and content. These developments are alarming for established players in the telecommunications and media sector, like operators, cable companies, policymakers, artists, publishers, and copyright holders. Established players try to develop "killer apps" but don't know how that can be done. Start-ups, without having to make large investments, use the Internet as a platform for new services and applications. Thus, outsiders are able to deliver radical innovations.

Whether it be phoning, watching TV, or online gaming, the underlying communication is more and more based on IP, making it increasingly difficult - as well as artificial - to continue to make a distinction between voice, content, and other communications services. Regulation of electronic communication and networks, as we know it within the European Union (EU), is attempting to gradually adapt to this new reality. There has been much consolidation between providers of fixed, mobile and cable networks in recent years. The idea prevalent in the 1990s that competition amongst telecommunications infrastructure providers would soon flourish is open to dispute. Is the regulatory framework, which has been effective in managing the liberalized market in the first ten years, equipped for the future of convergence?

The question about the success of liberalization of telecommunications is usually addressed 
from the (narrow) perspective of voice telephony and penetration of broadband Internet access. ${ }^{1}$ From such a viewpoint, it is relatively straightforward to make an assessment. The telecommunications market has developed enormously since liberalization and privatization. However, given the revolutionary developments related to the Internet, one also has to take a broader perspective, to look ahead, and to consider future generations of users. This article evaluates the recent past in which competition was introduced in the Dutch telecommunications market, and takes into account the broader changes in telecommunications, the Internet, and media. In particular, as broadband networks are becoming an integral part of our vital infrastructures, it is important to profoundly consider the role of the government in broadband. From this wider perspective, this article provides general lessons for broadband policy and regulation that are relevant for the EU, the US, as well as other countries.

In particular, inspired by Noam, ${ }^{2}$ this article poses the question whether the current regulatory framework is equipped for the present situation and the future. ${ }^{3}$ This is a relevant question, all the more so since at the time of the liberalization of telecommunications in the Netherlands in 1998 there was a strong feeling that the market was engineerable. OPTA, the Dutch regulator, drew up its designs of the market and the necessary transition. Former monopolist KPN was exposed to competition and new regulations, and transformed itself into a commercial enterprise. Newcomers, who did not have their own networks from day one, would initially be entitled to make use of regulated access to KPN's existing infrastructure. A new phase began around 2008, with the emergence of next generation networks (NGNs) which make very high speed data traffic possible, for example via fiber-optic links to end users (FTTH), or cable connections upgraded on the basis of the DOCSIS 3.0 standard. In the Netherlands, it was believed that it would

\footnotetext{
${ }^{1}$ See e.g. Ministry of Economic Affairs, "Effecten Marktwerkingsbeleid," The Hague, The Netherlands (2008) for an evaluation in the Netherlands.

${ }^{2}$ Eli Noam, "Regulation 3.0 for Telecom 3.0," Telecommunications Policy 34, no. 1-2 (2010): 4-10.

${ }^{3}$ This paper draws partly on Paul W.J. De Bijl, "Liberalisering in Telecom: Missie Geslaagd, Operatie Afgerond?" in Preadviezen 2009: Marktwerking en Publieke Belangen, edited by Eric van Damme and Maarten Pieter Schinkel, (Amsterdam: KVS [Royal Netherlands Economic Association], 2009), 117-146.
} 
not take long, about five years, for the transition of the telecommunications market to be completed, and that regulation could then be phased out. The market has since developed considerably differently than was predicted at the time. Even though the market has developed very quickly, thanks to the thorough work performed by OPTA, this article argues that policymakers have overestimated the viability of competition in infrastructure. Following on from this, it is wise to take into account that the scale effects may well be so great that a return to a natural monopoly is a possibility that should not be excluded. If such a scenario becomes reality then we are, to a certain extent, back where we started, and we can consider the question of what is better for society: a private or a public monopoly. Of course, the situation is more complicated than that, but the point is that one should retain an open mind when considering how to structure the telecom sector and the adjacent media sector, in spite of the fact that in the eyes of some commentators, liberalization in telecommunications is as good as completed in the Netherlands. ${ }^{4}$

Related papers on the future of regulation in the telecommunications market include De Bijl and Peitz, ${ }^{5}$ Huigen and Cave, ${ }^{6}$ and Janssen and Mendys-Kamphorst. ${ }^{7}$ Also related is Lemstra, ${ }^{8}$ who details the differences between the Netherlands and the US and qualifies Noam. ${ }^{9}$ Lemstra notes that local (e.g. geographical) factors will continue to be of great importance for the likelihood of a broad FTTH roll-out. The discussion on more general lessons for broadband policy and regulation builds on a brief comparison of the situation in the Netherlands and the US. Schejter provides a very thorough comparison between the EU and the US and a fascinating discussion on what US

\footnotetext{
${ }^{4}$ Barbara Baarsma and Martijn Snoep, "Voeg toezichthouders NMA, OPTA en NZA en Consumentenautoriteit samen", Me Judice 3 (2010), October 22.

${ }^{5}$ Paul W.J. De Bijl and Martin Peitz, "Innovation, Convergence and the Role of Regulation in the Netherlands and Beyond," Telecommunications Policy 32, no. 11 (2008): 744-754.

${ }^{6}$ Jos Huigen and Martin Cave, "Regulation and the Promotion of Investment in Next Generation Networks - A European Dilemma.” Telecommunications Policy 3, no. 11 (2008): 713-721.

${ }^{7}$ Maarten C.W. Janssen and Ewa Mendys-Kamphorst, "Triple play: How Do We Secure the Benefits?"

Telecommunications Policy 32, no. 11 (2008): 735-743. See also P. Budde, "Global Regulatory Re-think Required," BuddeBlog, July 27, 2009, accessed January 16, 2011, http://www.buddeblog.com.au/global-regulatory-re-thinkrequired/.

${ }^{8}$ Wolter Lemstra, "Do We Need Policy 3.0 for Telecom 3.0? The Case of the Netherlands," Mimeo, Technical

University Delft, Dept. of Technology, Policy \& Management, Delft, The Netherlands (2009).

${ }^{9}$ Noam, 2010.
} 
broadband policy can learn from Europe. ${ }^{10}$

This article is structured as follows. The next section provides a review of the first decade after the liberalization of 1998 in the Netherlands. The following section deals with the second decade, and also looks ahead at what the near future may hold in store. The conclusion recapitulates the findings and briefly discusses issues that will become more prominent in the near future.

\section{The First Decade after the Dutch Liberalization (1998-2007)}

\subsection{A Promising Start}

In 1987, electronic communications policy in the EU started aiming at liberalization. ${ }^{11}$ In 1998, this resulted in the liberalization of all telecommunications services and networks. The regulatory package introduced in 1998 had to manage the transition from monopoly to competition. In 2002, the 1998 framework was reviewed in the light of convergence of telecommunications, the Internet, and broadcasting. The outcome was a new framework that came into effect in 2003 . The regulators in the member states of the EU (national regulatory authorities) have to implement the regulatory framework in the EU, which, due to ongoing revisions in response to market and technological developments, can be seen as a work in progress. In particular, based on the markets set out in the Commission's Recommendation on relevant markets, each regulator has to define the relevant markets while taking into account national circumstances. To do so, they carry out market analyses and assess whether effective competition exists in these markets. In case there is insufficient competition in a certain market, the national regulator has to draft regulatory measures and submit them for approval to the Commission. Note that the regulatory framework continues to

\footnotetext{
${ }^{10}$ Amit M. Schejter, “'From All My Teachers I Have Grown Wise, and From My Students More than Anyone Else': What Lessons Can the US Learn from Broadband Policies in Europe?" International Communication Gazette 71, no. 5 (2009): 429-445.

${ }^{11}$ For a brief overview and entries into background information from the European Commission, see "Telecoms in the European Union", accessed at January 23, 2011, http://ec.europa.eu/information_society/policy/ecomm/index_en.htm.
} 
develop: in 2009, a new agreement on reform was reached. Part of the update was tighter cooperation between national regulators, in the form of a new European telecommunications body BEREC (Body of European Regulators of Electronic Communications), in order to achieve more consistency of regulation among member states. The rules of the past revision have to be transposed into national laws by May 2011.

In the market for fixed-line telephony, rolling out new networks requires substantial investments and time. Nonetheless, when the Dutch market was opened up in 1998, insiders expected that facilities-based competition (competition between operators with their own networks) would not take all that long to arise, perhaps within about five years. ${ }^{12}$ At the time, the initial feeling that the market could be engineered seemed very reasonable in the Netherlands. At least two new entrants with the potential to provide nationwide coverage were waiting in the starting blocks. ${ }^{13}$ One of them was a consortium of various power and cable companies in the Netherlands under the name Enertel (later to become Energis) which, thanks to the power companies' own communications networks, already had a nationwide backbone (network comprising trunk connections) as well as finely meshed networks to end users consisting of the cable networks. The other was Telfort, an alliance between NS (Dutch national railways) and British Telecom, which combined NS's own nationwide communications network with telecom expertise from abroad. In addition to these two players, who within a reasonable timeframe would be able to develop into competitors of KPN with their own networks offering nationwide coverage, there was also the prospect of local entrants in market segments. It was believed that after making the necessary adjustments to their networks, regional cable companies would be in a position to add telephony to their product range. Amsterdam-based cable firm A2000 (later to become Priority Telecom and

\footnotetext{
${ }^{12}$ The aim, or at least hope, was to achieve competition that is effective (i.e., leading to reasonably low prices, innovative products and variety for consumers, both in the short and long term) and sustainable (i.e., it can remain effective without ex ante intervention by the government). For the sake of argument, implicitly I define the "success" or "failure" of regulation relative to the achievement of this intended goal. Therefore, this paper cannot be viewed as an evaluation of the achievements of the Dutch regulator.

${ }^{13}$ The description of the developments following the liberalization of the telecoms market in 1998 are partly taken from Paul W.J. De Bijl and Martin Peitz, Regulation and Entry into Telecommunications Markets, Cambridge, Cambridge University Press, 2002.
} 
UPC) had serious aspirations in this area at an early stage. ${ }^{14}$

Approximately five years later the picture had changed compared with initial expectations. Enertel and Telfort had failed to develop into nationwide competitors to KPN. Cable companies initially showed little interest in the market for voice telephony. The market for fixed-line telephony, characterized by a series of mergers and acquisitions which were accompanied by changes in strategy, therefore developed in a different direction than foreseen. Nonetheless, the developments that were observed still held out the promise of growth into a mature market. Various entrants rolled out networks for the business market in a very targeted manner at well-chosen locations. Colt, for example, had a backbone in combination with four fiber city rings, GTS had its own European backbone and an "interconnection point" in Amsterdam (where calls could be routed onto the KPN network), MCI Worldcom had a backbone and networks in Amsterdam and Rotterdam, and Versatel had a backbone extending beyond the national borders with a ring linking the major cities in the Netherlands. The city rings in the major cities had lines branching off to connect directly with large companies. However, the construction of connections to end users failed to materialize in most parts of the country, and particularly for residential customers.

In spite of the absence of competition in infrastructure for residential end users, consumers nonetheless benefited from price competition since OPTA ensured that KPN opened up its network to competitors without their own network. Scarlet Telecom and Tele2, for example, offered "Carrier Select" and "Carrier Preselect" services using the possibility of completing calls on KPN's network at low wholesale rates. In this way various players quickly claimed a share of the voice telephony market. The former monopolist was also obliged to unbundle the local loop, ${ }^{15}$ although competitors made little use of this facility in the first few years. The cause of this can probably be traced back to the relative unattractiveness of the business case that new entrants could build based on the

\footnotetext{
${ }^{14}$ A2000 carried out its first experiments with telephony back in 1997. See "Telefonie via kabel in Amsterdam" Computable, January 16, 1997, accessed on January 23, 2011, http://www.computable.nl/artikel/nieuws/211001/250449/telefonie-via-kabel-in-amsterdam.html.

${ }^{15}$ In local loop unbundling, a competitor rents local lines from the incumbent in order to offer its own services to end users over those lines. Calls are therefore not completed per minute, as is the case with Carrier Select.
} 
unbundled offering. The offering of telephony services based on Carrier (Pre)Select is conducted largely by means of administrative or account settlements in combination with marketing and sales activities, with modest investments related to infrastructure. By contrast, unbundled access demands, to a certain degree, investments up to a relatively deep level in KPN's network hierarchy. ${ }^{16}$ The expected revenues from voice telephony were apparently too low compared with the investments that had to be made.

So, in roughly the first five years following liberalization, segmentation took shape between (1) the large corporate market at attractive, concentrated locations in or near large cities; and (2) the rest of the market, consisting of consumers and SMEs in all areas as well as larger corporate clients in the areas outside the large cities or concentrated locations. So far, network rollout was primarily based on local circumstances and cost characteristics. It was hoped and expected that, with a little more time, entrants would also roll out networks in the second segment.

\subsection{Intermezzo: The Economic Philosophy behind Network Access Regulation}

Thanks to regulated network access, consumers were not deprived of competitive pressure on phone charges in the period when new firms were entering the market, possibly rolling out networks of their own. Economists labeled this approach the "ladder of investment": intervention by the regulator is such that newcomers are encouraged gradually to make investments that reduce their dependence on established network operators. ${ }^{17}$ The European regulatory framework for telecommunications stipulated the conditions which the access tariffs for the various forms of network access have to meet. ${ }^{18}$ For example, the access tariff for the unbundled local loop for

\footnotetext{
${ }^{16}$ Based on the size of the necessary investments, market access via unbundling can be labeled an intermediate form of competition in services and infrastructure.

${ }^{17}$ Martin Cave, "Encouraging Infrastructure Competition via the Ladder of Investment," Telecommunications Policy 30 , no. 3-4 (2006): 223-237.

${ }^{18}$ For an overview see Buigues, Pierre A. and Patrick Rey. The Economics of Antitrust and Regulation in

Telecommunications: Perspectives for the New Regulatory Framework. Cheltenham/ Northampton, MA: Edward Elger,
} 
network operators with significant market power (SMP) had to be "cost-oriented," that is, based on underlying costs. ${ }^{19}$ At the same time access tariffs had to be cost-effective and make it possible for the network operator to obtain a reasonable rate of return.

The regulated access tariffs constitute a key variable in the development of the telecommunications market. Economists were quick to warn against the risk that network access regulation can disrupt the rollout of competing networks. ${ }^{20}$ Low access tariffs stimulate competition in services, but discourage new entrants from investing themselves in a network, so that regulation of network access will continue to be necessary. Supplementary to this, Van Damme indicated that the expectations (consciously or unconsciously) maintained by the regulator itself regarding the prospects of network roll-outs could become a self-fulfilling prophecy. ${ }^{21}$ A more pessimistic regulator will take a tougher regulatory stance and hence suppress the investment incentives for new entrants (and vice versa). An empirical study suggests that a lower wholesale charge for the unbundled local loop encourages new entrants to make use of the unbundled offering, and that this is at the expense of network roll-out. ${ }^{22}$ Grajek and Röller conclude, based on empirical research using data from the EU, that tougher network access regulation leads to reduced investment and that stimulating competition with network access regulation lowers the incentives to parties to roll out their own networks. ${ }^{23}$ The situation is undoubtedly more complex, but these empirical indications tie in with the previously expressed intuition on the basis of economic arguments.

The European regulatory framework recognized the risk of undermining the incentives for

\footnotetext{
2004.

${ }^{19}$ Regulation (EC) No. 2887/2000 of the European Parliament and of the Council of 18 December 2000 on unbundled access to the local loop.

${ }^{20}$ For example, see CPB, "Competition in Communication and Information Services: Opportunities and Obstacles," Bijzondere Publicatie 12, The Hague, The Netherlands (1997); and Eric E.C. van Damme, "Competition in the Local Loop," Visions, study, VECAI, The Hague, The Netherlands (1999).

${ }^{21}$ Van Damme.

${ }^{22}$ LECG, "Access regulation and infrastructure investment in the telecommunications sector: An empirical investigation", Londen (2007). This study was sponsored by ETNO (European Telecommunications Network Operators' Association), an association of major incumbent operators.

${ }^{23}$ Michal Grajek and Lars-Hendrik Röller, "Regulation and Investment in Network Industries: Evidence from European Telecoms," Working Paper No. 09-004, European School of Management and Technology (ESMT), Berlin, Germany (2009).
} 
network roll-out and prescribed as follows with respect to the unbundling of the local loop: "Pricing rules for local loops should foster fair and sustainable competition, bearing in mind the need for investment in alternative infrastructures [...]." ${ }^{24}$ The Access Directive of 2002 referred more specifically to the importance of network roll-out:

"The imposition by national regulatory authorities of mandated access that increases competition in the short-term should not reduce incentives for competitors to invest in alternative facilities that will secure more competition in the long-term.",25

Not only is it difficult to design network access regulation while safeguarding investment incentives, it is not evident that it is possible at all.

To see this, let parameter $a$ denote the level of the access tariff such that a new entrant is indifferent as to whether it purchases access or installs its own infrastructure. If the access tariff is $t$ $>a$, this entrant will therefore want to construct a network itself. Let $c$ denote the entrant's marginal costs per connection and $b$ the maximum willingness to pay for a connection. The perceived marginal costs are therefore $c+t$. If $t+c>b$ then there is no viable business model for new entrants wishing to roll out a network. Parameter $a$ is difficult to assess, so that it is difficult to estimate whether access price $t$ has not been chosen at too low a level. Furthermore, the Access Directive is implicitly based on the assumption that $a<b-c$, that is, the interval $[a, b-c]$ within which $t$ has to be chosen is not empty. Naturally, this stylized representation is a simplification, but it nonetheless points to fundamental questions to which, at the end of the day, only practice can provide an answer.

\footnotetext{
${ }^{24}$ European Community, Regulation (EC) No. 2887/2000 of the European Parliament and of the Council of 18 December 2000 on Unbundled Access to the Local Loop (Official Journal of the European Communities, 30 December 2000, art. 11, p. L 336/5).

${ }^{25}$ European Community, Directive 2002/19/EC of the European Parliament and of the Council of 7 March 2002 on Access to, and Interconnection of, Electronic Communications Networks and Associated Facilities (Access Directive) (Official Journal of the European Communities, 24 April 2002, art. 11, p. L 108/110).
} 


\subsection{The Momentum Evaporates}

How did the market develop after such auspicious beginnings, which had given rise to the hope of a healthy development towards competition in infrastructure within a reasonable timeframe? Let us first examine more closely the experiences with network access regulation. Within the outlines that had been established, the European framework made shaping access regulation a matter for the national regulatory authorities. In the Netherlands, OPTA had devised a sophisticated solution for the dilemma concerning investment incentives that had been identified by economists. This consisted in allowing the regulated price for the unbundled local loop to rise gradually over a five-year period. This was in line with the principle of the notion of the "ladder of investment" - a concept that had also been embraced by the European Commission. The underlying idea is to encourage new entrants to climb up in a stepwise fashion, starting from a position as service provider using the incumbent's network, and by gaining experience and market share to end as an operator with its own network. ${ }^{26}$ Such climbing happens automatically when higher rungs on the ladder are more profitable than the rung currently occupied by the new entrant. A higher rung is reached in this way by making an investment which adds less easily replicable network elements to the assets of the new entrant. ${ }^{27}$ The incentives to do so are strengthened even further when new entrants fear that the rung they currently occupy will be taken away from beneath their feet. It should be noted that if the intended investment is not cost-efficient (in the light of scale effects), a welfare loss can ensue.

OPTA had proposed the following formula for determining the access tariff for the unbundled local loop over time: $P_{t}=P_{t}^{H}+t\left(P_{t}^{E}-P_{t}^{H}\right) / 5, t=0,1, \ldots ., 5$ (years). ${ }^{28}$ The starting point was a tariff $P_{0}=P_{0}{ }^{H}$ based on historical costs, and the end point $P_{5}=P_{5}{ }^{E}$ based on current

\footnotetext{
${ }^{26}$ Martin Cave "Making the Ladder of Investment Operational," Mimeo, Warwick Business School, University of Warwick, United Kingdom (2004).

${ }^{27}$ Based on the concept of replicability of network elements.

28 "Richtsnoeren met betrekking tot ontbundelde toegang tot de aansluitlijn ('MDF-access')," OPTA, March 16, 1999/OPTA/J/99/1443.
} 
costs. Thus, $P_{t}$ would gradually increase and reach the level of the current costs. This would make it relatively unattractive for new entrants to continue to rent the local loop as opposed to installing a network themselves. The five-year time span was apparently considered as representative for a minimum period within which the necessary substantial investments could be recouped. OPTA's plan did not work out as intended, however. ${ }^{29}$ This was because no one had foreseen that the current costs could also decrease. The latter happened because the costs could gradually be spread across an increasing number of local lines. The European requirement of cost orientation implied that the regulated price $P_{t}$ went down instead of up. This ensured low-threshold access to new entrants also at the end of the envisaged horizon - precisely the opposite of what was intended. The European framework therefore appeared to be too constrictive for the long-term strategy of the Dutch regulator. It is relevant to ask whether the original idea of an increasing access tariff was not already at odds with the European framework from the start. Another interesting question is whether a longterm approach, requiring commitment over a period of more than just a few years, is not asking too much of a regulatory authority. Actually, regulated wholesale rates continued to decrease, from $€ 13$ in 2002 to $€ 6$ in 2010 . $^{30}$

As already remarked, new entrants apparently did not consider access to the unbundled local loop attractive enough to put voice telephony alone on the market. This changed a few years later with the emergence of broadband Internet over DSL, a service that allowed a more attractive business case to be built. All the more so due to the low rental price for the unbundled local loop, which also compared favorably in an international context. In the period between January 2003 and December 2004, the number of lines acquired by new entrants increased at breakneck speed, from zero to more than $400,000 .{ }^{31}$ Tiscali and XS4ALL are two of the Internet providers who initially offered broadband Internet via unbundled local loops. This entry to the new market segment

\footnotetext{
${ }^{29}$ Paul W.J. De Bijl and Martin Peitz, "Local Loop Unbundling in Europe: Experience, Prospects and Policy Challenges," Communications \& Strategies 57, no. 1 (2005): 33-57.

30 "FTTH in The Netherlands 2010 Q1," Stratix Consulting, Hilversum, The Netherlands (2010).

${ }^{31}$ De Bijl and Peitz, 2005.
} 
initially led to widespread competition in subscription rates for broadband Internet access. In the following years, however, KPN acquired various competitors who were using unbundled access. The high rate of broadband penetration, which was strongly driven by unbundled access, nonetheless placed the Netherlands firmly at the top in international comparative surveys between countries. At the start of 2009, for example, the average broadband penetration rate in the EU was 24\%. The Netherlands (together with Denmark) were out in front with a broadband penetration rate of almost $37 \% .{ }^{32}$ In doing so they had easily overtaken Korea (32\% in the fourth quarter of 2008), which had been the international front runner for many years. ${ }^{33}$

Perhaps helped by the failure of OPTA's plan for implementing a rising wholesale tariff, local loop unbundling (LLU) eventually became a great success, as illustrated above. Indeed, it could be argued that this success was precisely due to the fact that the access price remained low, so enabling new entrants to build an attractive business case based on renting unbundled lines in the local loop from KPN. The strong growth in the number of companies who consequently marketed an attractive offering for broadband Internet gave the Netherlands a leading position in terms of broadband Internet use. But how was it going with the roll-out of competing networks?

It was noticeable that many players who were using access to KPN's local loop did not take the step towards rolling out lines to consumers' homes. They did, however, invest in network rollout to the local exchanges - this nonetheless gave a strong impulse to the market. In addition, it appears that the dynamism in the wholesale market segment, which initially showed a strong tendency towards competition in infrastructure, has decreased over the past few years. It is still too early to be able to say so precisely, but the favorable picture (in terms of network rollout) has become blurred. At some point, there even seemed to be a standstill amongst network operators, which may possibly be explained by the wish of wholesale customers to purchase an integrated

\footnotetext{
${ }^{32}$ European Commission, 14th Report on the Implementation of the Telecommunications Regulatory Package - 2008, last accessed Jan. 16, 2011, http://ec.europa.eu/information_society/policy/ecomm/library/communications_reports/annualreports/14th/index_en.ht m.

${ }^{33}$ OECD Broadband Portal, last accessed Jan. 16, 2011, http://www.oecd.org/sti/ict/broadband.
} 
package of communications services (voice and Internet, and possibly also mobile) from a single provider. This would take the wind out of the sails of new entrants who cannot offer a total package of services. Huigen and Cave are not optimistic about the investments in fixed-line local loops and point out that the recent review of the EU regulatory framework failed to produce an adequate response in this regard. ${ }^{34}$ The European framework still proceeds on the implicit assumption that the necessary investments will eventually come along.

The cable companies had meanwhile also entered the broadband Internet market segment, as a supplement to the transmission of TV programmes. The addition of voice telephony (voice over broadband) to the bundle of services already being offered resulted in competition in triple play bundles. In some municipalities, optical fiber networks (FTTH) were rolled out to end users by new players, such as Reggefiber, or by the municipalities themselves in collaboration with private parties. KPN entered the market for TV programs with digital wireless technology (under the name Digitenne). This had the effect of increasing consumer choice in a market no longer consisting of telephony alone, but also of the Internet and media.

Looking back, various questions present themselves. One important question is, first, whether network access regulation was perhaps too stringent (i.e. that access prices such as LLU rates were set too low), thereby choking the incentives for network rollout. This question is difficult to answer, but there is nonetheless empirical material available to confirm such a mechanism. Furthermore, the gradual phase-out of network access regulation has proved difficult in practice. OPTA's conspicuous attempt to do so was ultimately rendered impossible by the requirement of cost orientation within the European regulatory framework. De Bijl and Peitz call for a widening of the market definitions in conformity with the business strategies focused on triple play bundles, combined with a fully symmetrical regulation of KPN and the cable companies. ${ }^{35}$ Knieps discusses the increased complexity, which is accompanied by internal inconsistencies, of European

\footnotetext{
${ }^{34}$ Huigen and Cave, 2008.

${ }^{35}$ De Bijl and Martin Peitz, 2008.
} 
regulations and calls for regulations to be restricted to monopolistic bottlenecks aimed at phasing out network access regulation. ${ }^{36}$ The overarching question is whether the current European framework should not be subject to a thorough overhaul. Another question, following on from this, is whether the blueprint of competition in infrastructure is actually feasible. This question will be addressed below.

\subsection{The Intensity of Competition}

Taking stock of ten years of regulation, it is unclear whether by now we have arrived at a situation of effective competition in infrastructure. OPTA considered the question of whether two networks are sufficient to guarantee competition and came to the conclusion that this is not the case. ${ }^{37}$ Nonetheless, a duopoly could, in theory, result in sufficient competition since voice telephony and broadband Internet are basically commodities, with vertical quality aspects, such as speed of connection, as the principal distinguishing features. Where there is strong competition on price (without a "jungle" of complicated subscriptions), any differences in price can be traced back to differences in quality (e.g. the speed of a connection) or underlying costs.

The possibility that access will be provided voluntarily to service providers strengthens the argument that a duopoly can lead to sufficient competition. Bijlsma and Van Dijk argue that competition for market share between vertically integrated networks creates incentives to (voluntarily) admit new entrants. The idea is that if one network fails to offer access, the other network, by providing access, can lure subscribers away from the first network and earn revenues from them at wholesale level. The authors show that, irrespective of the type of competition in the end user market, there will be no exclusion of service providers unless there is a sufficiently high

\footnotetext{
${ }^{36}$ Günter Knieps, "Telecommunications Markets in the Stranglehold of EU Regulation: On the Need for a Disaggregated Regulatory Contract," Journal of Network Industries 6, no. 2 (2005): 75-93.

${ }^{37}$ OPTA, "Is Two Enough?" Economic Policy Note no. 6, The Hague, The Netherlands (2006).
} 
degree of horizontal differentiation between the networks. ${ }^{38}$ In other words, a duopoly of networks accompanied by service providers who require network access can, under certain conditions, itself ensure sufficient competition at the wholesale level. In time, when networks find and implement ways of setting themselves apart from one another, this will possibly no longer be the case. Therefore, while regulated network access may not be necessary at the moment, it should nonetheless remain available as a tool of regulation to be used if the intensity of competition weakens due to consolidation and the creation of niches. ${ }^{39}$

Note that network operators, fixed and mobile alike, have by nature a strong incentive to wrest themselves from the "commodity trap." The means of doing so is to introduce horizontal differentiation of services, for example by aiming for different target groups with the aid of advertising and marketing, or by offering distinctive content profiles. In this way, one network could focus (relatively) more on sports and entertainment while the other network focuses on culture and news, for example. Such differentiation strategies can be strengthened by offering exclusive content, such as live broadcasting of sports events. There is already some activity in this area, for example the broadcasting of live football matches by operator Tele2. Moreover, the discussion about network neutrality is highly relevant in this context, since an important way that networks may differentiate themselves from one another, is to make the Internet "less neutral" (this issue will be revisited below).

Do mobile telephony and mobile Internet represent a serious substitute capable of placing competitive pressure on the fixed-line networks? The market for mobile telephony was able to develop into a competitive market within a short period of time. The reason is the difference in investment costs: mobile telephony does not require any digging work to enable a roll-out of finely meshed connections to end users. Due to consolidation, there are currently three network operators

\footnotetext{
${ }^{38}$ Michiel Bijlsma and Machiel van Dijk, "Nieuwe Generatie Netwerken, Nieuwe Generatie Regulering?” CPB Document 145, CPB, The Hague, The Netherlands (2007).

${ }^{39}$ Paul W.J. De Bijl and Martin Peitz, "Innovation, Convergence and the Role of Regulation in the Netherlands and Beyond," Telecommunications Policy 32, no. 11 (2008): 744-754.
} 
left (KPN, Vodafone, and T-Mobile). While it is hoped that fixed and mobile will move closer to one another in terms of speed, so that they become more interchangeable, the current framework correctly considers them as separate markets. That could, in principle, change in the future, due to technological progress (such as the next generation of mobile telephony, 4G). However, by the time that this becomes a reality, fixed-line networks will also have developed further. It is therefore debatable whether the gap between fixed and mobile infrastructure will ever be closed. Cave and Hatta assume that for the time being a persistent gap will exist between fixed and mobile equivalent to mobile being four years behind fixed. ${ }^{40}$ Under this assumption, therefore, the speed of fixed-line telephony will remain of a higher order of magnitude than mobile. Nevertheless, if content and applications were to reach the "end" of their development in terms of demand for speed at some point in time - in other words the demand for higher bandwidths with a continuing innovation in electronic services were eventually to level off - then a permanent gap in speeds is not necessarily problematical in the long run. We should not count on this though. History shows a continuous growth in demand for computing and transmission speeds. One can easily imagine services, peer-topeer high definition video, for example, that will heavily utilize the capacity of the new generation of networks. It is therefore sensible to take seriously the possibility that mobile connections will not offer a full-blown substitute for fixed-line networks for some time to come. See, for example, Huigen and Cave and the references in their work: they assume that wireless links are not suitable for services such as HDTV. ${ }^{41}$ In the shorter term, perhaps the coming five years, that will certainly not be the case. On the other hand, it is clear that fixed-line and mobile networks are becoming increasingly intertwined, for example through the use of wireless technology (e.g. WIMAX) to establish fixed wireless connections as a cost-efficient alternative to optical fiber.

In summary, there is no easy answer to the question of whether two networks are sufficient

\footnotetext{
${ }^{40}$ Martin Cave and Keiko Hatta, "Transforming Telecommunications Technologies — Policy and Regulation.” Oxford Review of Economic Policy 25, no. 3 (2009): 1-18.

${ }^{41}$ Jos Huigen and Martin Cave, "Regulation and the Promotion of Investment in Next Generation Networks - A European Dilemma," Telecommunications Policy 3, no. 11 (2008): 713-721.
} 
to guarantee competition. While it may be possible that regulated network access is no longer necessary at the moment, this has yet to be proven in practice. In addition, networks can be expected to think up new ways of reducing competition. Two networks may be sufficient at the moment, but that may all change in the future. Note that waiting for effective competition in infrastructure, even if it takes longer than expected, is in itself not a problem. Maybe it is simply a question of being more patient. This may indeed be the case if certain conditions are met. First, stimulating competition in services may not undermine the incentives for network roll-out. This point was discussed earlier: it is inherently difficult to implement network access regulation in a dynamically efficient manner, both in terms of design (level of access prices in relation to underlying costs and willingness to pay) and in terms of fitting into the complex European framework. Second, the assumption of substantially decreased scale effects, on which liberalization was jointly based, must remain valid (in so far as it had already been met). The question, therefore, is whether sustainable competition in infrastructure is viable The next section discusses this question in the light of the emergence of NGNs.

\section{The Second Decade after Liberalization (2008-2017)}

\subsection{Further Market Developments}

Where liberalization and privatization stimulated a profusion of innovation and (regulated) competition, we are now witnessing the emergence of broadband networks, and in their wake an enormous variety of new online services. Some of these services have an impact on societal and social communication structures (e.g. Google, Twitter, Facebook, etc.). Others have the effect of destabilizing existing market structures (e.g. YouTube, iTunes). It is mainly start-ups or outsiders that produce surprising, radical innovations. The traditional players in the telecommunications 
market are not structured for such innovations. ${ }^{42}$ The further development of the market for electronic communications is nonetheless heavily dependent on them, because the greater bandwidth of NGNs continually creates new opportunities for providers of services and applications who wish to use the new networks.

Huigen and Cave argue that it is likely that there will be no major investment in fixed local loops, initiated by the private sector, in most member states of the EU. ${ }^{43}$ Some industry observers are also pessimistic about the business case for upgrading the existing copper and coaxial networks. ${ }^{44}$ The Netherlands could be an exception, since this country has an excellent starting position for sustainable competition between networks. Almost every household can already choose between DSL and cable modem for broadband Internet. Roughly $6 \%$ of the broadband connections in the country are optical fiber connections. ${ }^{45}$ This can rise to anything between $35 \%$ and $42 \%$ in 2013 and if KPN goes through with earlier announced plans, it should be possible to attain almost full coverage of $95 \%$ within two decades.

The Netherlands has one of highest rates of broadband penetration in the world and has a better starting position than most other countries, but that does not mean that effective competition in infrastructure is feasible in the future. The business propositions of many new entrants without plans to make substantial investments were based on the possibilities of administrative arbitrage created by network access regulation - business models that still have not lost their attractiveness, due to the regulatory environment. However, continued growth towards facilities-based competition was part of the market development foreseen within the European framework. As was discussed in previous section, this outcome has yet to crystallize. In addition to this, consumers were subject to

\footnotetext{
${ }^{42}$ Andrew Odlyzko, “Telecom dogmas and spectrum allocations," Mimeo, Digital Technology Center, University of Minnesota, Minnesota (2004).

${ }^{43}$ Huigen and Cave, 2008.

${ }^{44}$ P. Budde, "The FttH versus Cable Debate Misses the Point,” BuddeBlog, July 21, 2009, last accessed Jan. 16, 2011, http://www.buddeblog.com.au/the-ftth-versus-cable-debate-misses-the-point/.

${ }^{45}$ Ibid.
} 
aggressive, and sometimes misleading, sales methods (e.g. slamming). ${ }^{46}$ Customers were sent incorrect invoices and demands for payment, were sometimes left with no working connection for quite long periods when they switched providers and were kept on hold by helpdesks for lengthy periods, only to be eventually brushed off with the remark to check the website. The result is that the perceived costs of switching from one telecom operator or Internet provider to another are still significantly high. Consumer confidence in new entrants and in the switching process has been dented. Admittedly, the size of this problem is unclear, but these are not insignificant incidents. Any restoration of consumer confidence will presumably have to come from sustainable competition, in other words competition that can stand on its own legs, and will have to take the place of competition in services made possible by regulation. Arguably, however, that sustainable competition still appears to be just as far away as in 1998, at the start of liberalization.

A qualification needs to be made at this juncture. It is striking that in the US two networks (supplemented with mobile networks) are considered sufficient to dispel the need for regulation of network access. ${ }^{47}$ The empirical counterfactual for the Dutch situation is absent, however, because network access regulation still occupies a prominent position. Nevertheless, one should not rule out that effective competition in infrastructure may already be a realistic option, all the more so if the existing DSL and cable networks were to be treated entirely equally, namely as providers of triple play bundles (voice, Internet and TV), without too much horizontal differentiation. At present, given the monopoly rights that cable operators have with respect to TV programs, there is no level playing field, so one cannot assess whether two nationwide networks would compete intensely without access regulation. With a level playing field, competition would probably concentrate more on gaining a competitive advantage by offering higher capacities and upgrading the networks. ${ }^{48}$ In spite of the unclear picture regarding the direction in which network roll-out is

\footnotetext{
${ }^{46}$ See e.g. ZDNet, "Meeste klachten over sms en slamming”, May 19, 2009, last accessed Jan 23, 2011, http://www.zdnet.nl/news/102651/meeste-klachten-over-sms-en-slamming-/.

${ }^{47}$ Cave and Hatta, 2009.

${ }^{48}$ De Bijl and Peitz, 2008.
} 
developing, there is a lot of activity in the sector. ${ }^{49}$ The large cable operators respond to the gradual uptake of FTTH by introducing DOCSIS 3.0, the most recent standard for high-speed data transport over cable. KPN, the former monopolist, is investing in upgrading its backbones., but nevertheless, the move by cable put pressure on KPN with respect to its ambition of large-scale FTTH rollout. Some industry observers view DOCSIS 3.0 as a threat to KPN, due to its relatively low investment cost. $^{50}$ The largest CLECs, the DSL-platform operating competitors Tele2, BBned and Online, are postponing the rollout of FTTH, relying on VDSL2 from the Central Office in response to cable's introduction of DOCSIS 3.0. ${ }^{51}$ Among these competitors, Tele2 took over BBned (acquiring the provider from Telecom Italia) earlier this year. ${ }^{52}$

At the same time, there have been various initiatives to roll out FTTH. For instance, Reggefiber is prominent with its activities to roll out networks in various municipalities. Since 2008, KPN has participated in Reggefiber via a joint venture construction as part of its "all-IP" strategy. The question remains whether nationwide coverage is getting closer, a development that policymakers certainly hope to see. Nonetheless, where the Netherlands Competition Authority (NMa) initially hesitated to give approval for the joint venture, it eventually agreed to a remedy which (among other things) consisted in implementing a functional and operational separation between the joint venture and parent company KPN, in combination with an obligation to provide non-discriminatory open access based on reasonable prices. ${ }^{53}$ This remedy, based on "repairing" market concentration through mandatory access, implicitly shows an increased pessimism about the long-term feasibility of competition in infrastructure.

A recent example illustrates that the market tends to ignore regulatory blueprints: instead of nationwide rollout of competing networks, the action takes place at the local level and in specific

\footnotetext{
${ }^{49}$ See for example Lemstra, 2009.

${ }^{50}$ Webwereld, "Upgrade kabelnet bedreigt uitrol glasvezel KPN", April 22, 2009, last accessed on Jan. 23, 2011, http://webwereld.nl/nieuws/57208/upgrade-kabelnet-bedreigt-uitrol-glasvezel-kpn.html\#source=head.

51 "FTTH in The Netherlands 2010 Q1."

52 “Tele2 Buys bbned," Light Reading Europe, July 16, 2010, last accessed Jan. 16, 2011, http://www.lightreading.com/document.asp?doc_id=194484.

${ }_{53}$ Nederlandse Mededingingsautoriteit, Besluit nr. 6397 / 274, “6397/KPN - Reggefiber”, July 28, 2009.
} 
market segments. Mobile operator Vodafone Netherlands and Eurofiber, a wholesale supplier of fiber networks, recently announced plans for joint rollout of FTTH, targeting corporate customers. ${ }^{54}$ Thus, facilities-based competition is materializing in its own peculiar way. This is, in itself, good news, but residential end users will not benefit from it. Moreover, it should be noted that Eurofiber belongs to Reggeborgh Groep, a private investment company, the same company that had started Reggefiber (in which incumbent KPN participates). Just like in mobile telecoms and LLU-based broadband Internet access, there are strong tendencies towards consolidation.

Is the approach of the European regulatory framework, based on allowing competition in infrastructure to grow under an extensive collection of pre-conditions and constraints, still effective? After all, the rollout of networks to end users has been less successful than originally expected and hoped for. The new generation of optical fiber networks requires high investments, perhaps too high for viable competition between several networks that are prevented from sharing the costs of their investment. There has even been consolidation in mobile telecommunications. At some point, we may simply have to accept that there is no way of halting the tendency towards monopoly formation.

\subsection{What Regulatory Response?}

In response to market developments, the European regulatory framework has been smoothed out and refined further over the years, by means of several reviews, but the underlying philosophy has remained the same. ${ }^{55}$ Let us look more closely at some recent developments in the Netherlands. First, it is striking that regulated LLU rates continued to go down over the years, from $€ 13$ in 2002 down to $€ 6$ in 2010 (Stratix, 2010). These low charges undermine the business case for fiber rollout, even though retail prices for broadband are relatively high in the Netherlands. Recall that

\footnotetext{
54 "Vodafone Netherlands, Eurofiber Partner on Business Fiber," Telecompaper, Sept. 1, 2010, last accessed Sept. 13, 2010, http://www.telecompaper.com/news/article.aspx?cid=754180.

${ }^{55}$ De Bijl and Peitz, 2008.
} 
OPTA initially tried to implement an increasing wholesale pricing scheme.

Another recent development is that OPTA, after about five years of preparation, recently imposed an obligation on the two largest cable companies in the Netherlands (UPC and Ziggo) for administrative resale of the analogue cable television to other parties. ${ }^{56}$ These parties would then be able to resell the connection, which they acquire administratively from a cable company, including programs to consumers. The decisions in this regard make clear that OPTA sees this measure as a means of stimulating competition in services on the analogue cable infrastructure in the near future, and in the longer term competition in infrastructure, with alternative market parties developing into providers of their own digital packages and platforms. However, the Trade and Industry Appeals Tribunal (College van Beroep voor het bedrijfsleven) overturned the market analysis that supported OPTA's decision. ${ }^{57}$ OPTA quickly responded by announcing it would redo its market analysis, thereby expecting a time horizon of about one year before a new decision can be taken. ${ }^{58}$

Arguably, the market is much more dynamic than the regulator's operational time horizon, even more so in the light of convergence and the increasing possibilities for intermodal competition. The market could be more effectively stimulated if the market for broadcasting distribution were no longer to be regarded as a separate segment and all networks were to be allowed to transmit all forms of electronic content (including TV and radio) under equal conditions. Note that it is not up to OPTA to reform media regulation, but to policy makers.

Are monopolies, due to the fact that scale effects have effectively never been away, a fact of life in the telecommunications sector? The belated arrival of NGNs strongly suggests so - although there is a possibility that the Netherlands may turn out to be an exception to the rule. For the time being, scale effects have a considerable impact on the development of network upgrading and

\footnotetext{
56 “OPTA stelt definitieve maatregelen en tarieven voor de kabelmarkt vast”, press release, OPTA, March 3, 2010.

57 “Tribunal Overturns OPTA’s Open Cable Ruling,” Broadband TV News, Aug. 18, 2010, last accessed Jan. 16, 2011, http://www.broadbandtvnews.com/2010/08/18/court-overturns-optas-open-cable-ruling/.

58 "OPTA start per direct nieuw onderzoek televisiemarkt - Uitspraak CBb biedt geen ruimte voor snelle openstelling tv-kabel,” Press Release, OPTA, Aug. 31, 2010, last accessed Jan. 16, 2011, http://www.broadbandtvnews.com/2010/08/18/court-overturns-optas-open-cable-ruling/.
} 
network rollout. After all, upgrading networks to optical fiber calls for significant investments. In addition, the telecommunications sector is not immune to the cyclical dynamics of the economy. ${ }^{59}$ The combination of (1) high fixed costs and very low marginal costs and (2) technological uncertainty ensures that adjustments in supply (e.g. network capacity) take place in fits and starts and with delayed effect. Periodic situations of over-capacity, such as could be seen during the dotcom bubble, are the result, temporarily leading to fierce price competition and low margins. This, too, has the effect of ensuring that, at best, competition in infrastructure forms a shaky balance. Are we back where we started? Noam notes a striking similarity with the public monopoly system before liberalization. While he acknowledges that there are differences (high-speed, crossing borders of countries and media, oligopoly instead of monopoly), he poses the question: "Have we come full circle?" ${ }^{60}$ Thus, Noam argues, the question for policymakers, given the market and technological developments, is whether the original policy approach going to work in the world in which we have arrived.

\subsection{The Need for Revising the Agenda for Policy and Regulation}

Various developments call for a revision of the agenda for policy and regulation in electronic communications and media. I will discuss the most important issues requiring an adequate response from policymakers and regulators. These issues are connected by an implicit view that the Internet can be seen as a general purpose technology, exhibiting huge spillover effects as well as characteristics of a critical infrastructure. Electronic communications provide huge spillover effects for the economy and society, as a lubricant for social interactions and economic transactions. For instance, in energy, data networks constitute the heart of smart grids. In health care, electronic interactions between doctors and patients can become more cost efficient. OECD estimates that in

\footnotetext{
${ }^{59}$ Eli Noam, "Fundamental Instability: Why Telecom is Becoming a Cyclical and Oligopolistic Industry," Information Economics and Policy 18, no. 3 (2006): 272-284.

${ }^{60}$ Noam 2010, 10.
} 
the Netherlands, assuming it costs $€ 1,000$ per household to connect all households in the country, it is socially profitable to do so provided this leads to cost savings of $1 \%$ (of total expenditures) in electricity, health care, transportation and education. ${ }^{61}$ The problem is, as Hogendorn argues, that network operators base their decisions on private revenues, and hence do not take into account the enormous value of the Internet for society and its contribution to economic growth. ${ }^{62}$

(a) Responding Adequately to the Patchwork Quilt, with Holes, of Facilities-Based Competition

The European framework is (still) based on the view that competition in infrastructure constitutes the final objective. Nevertheless, it is sensible to take into account the possibility that it will not happen, at least not on a nationwide scale. Even in the Netherlands, a densely populated country that started out as very promising after the liberalization, the market had its own way, despite the good intentions of the regulator. The emergence of facilities-based competition depends heavily on local conditions and cost considerations. Policymakers should therefore expand their view and consider (based on thorough cost-benefit analysis) a broader range of interventions, including full structural separation ${ }^{63}$ and public support for nationwide FTTH rollout. ${ }^{64}$ In various countries, such as Australia and New Zealand, interesting developments are taking place. Telecom New Zealand recently announced that it is considering structural separation, as a response to the government's Ultra-Fast Broadband initiative. In 2009, the Australian government announced that it was setting up a company which would invest AUD 43 billion (USD 30 billion) in a National

\footnotetext{
${ }^{61}$ OECD, "Network Developments in Support of Innovation and User Needs." Working Party on Communication Infrastructures and Services Policy. DSTI/ICCP/CISP(2009)2/FINAL (2009).

${ }^{62}$ Hogendorn, Christiaan, "Spillovers and Network Neutrality," in Regulation and the Performance of Communication and Information Networks, edited by Gerald Faulhaber, Gary Madden, and Jeffrey Petchey. Edward Elgar, forthcoming. ${ }^{63}$ Paul W.J. De Bijl, "Structural Separation and Access in Telecommunications Markets," Journal of Network Industries 6, no. 2 (2005): 95-114.

${ }^{64}$ See "New National Broadband Network", media release April 7, 2009, last accessed Jan. 23, 2011, http://www.minister.dbcde.gov.au/media/media_releases/2009/022. In various countries, including the Netherlands, the former incumbents appear to be willing to accept a future in which the government will play a more prominent role in the roll-out of NGNs, in combination with a model of open access. See P. Budde, "National Telcos Can and Will Change Their Behaviour,” BuddeBlog, Aug. 17, 2009, last accessed Jan. 16, 2011, http://www.buddeblog.com.au/national-telcos-can-and-will-change-their-behaviour/. See also Janssen and MendysKamphorst.
} 
Broadband Network over an eight-year period. Related, but at the same time not comparable, is the Dutch government's intention to give local authorities scope for investments in fiber-optic networks. The plan is to allow municipalities to participate in the building of networks, conditional on not distorting the market process. ${ }^{65}$

\section{(b) Responding Adequately to Convergence}

Based on the observed market developments, De Bijl argues that current forms of supervision and regulation of telecommunications and media should merge with the disappearance of the dividing lines between telephony, the Internet, and media. ${ }^{66}$ An important consideration is that the risks of market failure in the communications sector are substantial, and will remain so. They affect all ranks and levels of society and involve more than just the risk of abuse of market power. But the most important consideration is convergence. Until recently, the various departments and regulators involved in telecommunications and media had a reasonably clear picture of how interwoven electronic communications and media had become, and separate procedures and a limited degree of alignment were considered sufficient. That is now in the past. A merger along the sectoral dimension enables a better alignment, and also consistency, of regulation of electronic communication and electronic services, including broadcasting distribution and substantive aspects of content. The Internet has destroyed the segregation of different infrastructures and electronic services. In the Netherlands, one can argue that it makes sense to follow the example of the United Kingdom and merge the existing regulatory authorities for telecommunications and media (OPTA, Radio communications Agency Netherlands [Agentschap Telecom] and the Dutch Media Authority [Commissariaat voor de Media]) into a new regulatory authority, separate from the competition authority. $^{67}$

\footnotetext{
65 "Ruim baan snel Internet gemeenten," Het Financieele Dagblad, Sept. 9, 2009.

${ }^{66}$ Paul W.J. De Bijl, “The Need for a Communications Regulator: A Lesson from the Netherlands,” Mimeo, CPB, The Hague, The Netherlands (2010).

${ }^{67}$ Contrary to this line of reasoning, the State Secretary for Economic Affairs and the Minister of Education, Culture
} 
(c) Network Neutrality: Safeguarding an Open and Vibrant Internet

Network neutrality refers to the original pricing regime on the Internet, that does not make distinctions in terms of price (or in other ways) between bits or data packets depending on the way these bits and packets are used in applications and services. ${ }^{68}$ Thus, there is no favoring (or hampering) of specific content providers or groups of consumers. This is relevant since providers have incentives to abandon the regime of network neutrality so that they can charge end users and content providers different prices, based on the value of the content for them. The Internet would then become more like a walled garden, to some extent reflecting the traditional telecommunications model prior to the advent of the Internet, with each service being charged and paid for separately. It would also become more like cable, where the network operator determines which channels can be viewed. Arguably, investment incentives for networks could decrease if they are prevented from appropriating rents from users and content providers. It is open to debate whether this is the case or not. For instance, Economides argues that prioritization arrangements reduce efficiency and harm innovation. ${ }^{69}$ Frieden points at efficiency gains that can be realized through discrimination and prioritization, while recognizing that they may also have anticompetitive effects. ${ }^{70}$ In light of the spillovers of the Internet, most important are the issue of the Internet as an open platform for end users, and the accompanying tidal wave of bottom-up innovations.

It is often argued that in a competitive market, discrimination by providers will be corrected through consumers switching to other providers - especially if there are transparency requirements

\footnotetext{
and Science recently judged that the current structure of regulation and supervision is future-proof given the convergence in the market. "Elektronische communicatie en media: omroepdistributie en inrichting toezicht," letter, Mar. 10, 2009, ref. ET/EM/9038511.

${ }^{68}$ See for example Nicholas Economides, "The Economics of the Internet," In The New Palgrave Dictionary of Economics, 2nd Ed. London: Macmillan, 2007.

${ }^{69}$ Nicholas Economides, "Why Imposing New Tolls on Third-Party Content and Applications Threatens Innovation and Will Not Improve Broadband Providers' Investment," Working Paper \#10-01, NET Institute (2010).

${ }^{70}$ Rob M. Frieden, "Network Neutrality and its Potential Impact on Next Generation Networks," In The Selected Works of Rob Frieden, Mimeo, Pennsylvania State University. 2007.
} 
for networks, obliging them to disclose any network bias practice. However, competition in electronic communications is, at best, imperfect, and subject to further consolidation and a tendency toward a natural monopoly, as was discussed above. Moreover, network bias practices in themselves lead to a reduction of competition - that is what makes them attractive to providers in the first place. ${ }^{71}$ Transparency requirements may look good on paper, but have no bite if competition is ineffective in the first place.

\section{(d) Safeguarding the Critical Communications Infrastructure}

Utility sectors like energy and water have in common the fact that there are public interests at stake. Electronic communications is no different, despite the privatizations and liberalizations that have taken place. The question is how one can protect these public interests under the new regime. ${ }^{72}$ For instance, the prospect of not being able to use the telephone or Internet for several hours on end would be unthinkable to us. As is the case with a power failure, the country would quickly grind to a halt. It is therefore surprising that the possibility of this happening is not taken as seriously as the possibility of a mains power failure - in spite of the fact that it is still unclear whether and when the market is capable of standing on its own two feet. Just how safe are our networks? What would have happened to its infrastructure if KPN had gone bankrupt as a consequence of the enormous bid made in the UMTS auction in 2000? Do we have to worry about foreign acquisitions of national telecom providers? ${ }^{73}$ Is telecommunications law able to deal with threats of sabotage? It is remarkable, and also worrisome, in the light of the significant external effects of electronic communications for our society and economy, that these issues are sometimes shrugged off, as if competition can assume full responsibility for the control systems of the utility

\footnotetext{
${ }^{71}$ Viktoria Kocsis and Paul W.J. de Bijl, "Network Neutrality and the Nature of Competition between Network Operators," International Economics and Economic Policy no. 4 (2007): 159-184.

72 Hans De Bruijn and Willemijn Dicke, "Strategies for Safeguarding Public Values in Liberalized Utility Sectors," Public Administration 84, no. 3 (2006): 717-735.

${ }^{73}$ Warren G. Lavey, "Telecom Globalization and Deregulation Encounter U.S. National Security and Labor Concerns," Journal on Telecommunications and High Technology no. 6 (2007): 121-178.
} 
industries. At present, we run the risk that our regulatory systems have no adequate response to evolving threats to cyber security. ${ }^{74}$

\subsection{Europe and the US: Similarities and Differences}

To what extent are the policy challenges discussed in the previous sub-section relevant for different countries? To address this question, let us briefly compare Europe (represented by the country that was discussed in depth here, the Netherlands) and the US. Schejter offers an extensive comparison of policy regimes in the US and Europe. ${ }^{75}$ Here, I will briefly discuss a couple of prominent issues. Note, however, that the telecommunications sector is a complex dynamic system in which multiple equilibriums may exist. Such issues are beyond the scope of this discussion.

The main similarity between Europe and the US is that the characteristics of the industry are the same. Electronic communications is still very much a natural monopoly that plays a role as a public utility. The market structure is an oligopoly and public interest considerations are very prominent. Nevertheless, the sector is treated as if it can, gradually, be deregulated and left to competitive forces. This is a central element of the European regulatory framework, and it is also recognized in the recently published US National Broadband Plan (NPB) of the Federal Communications Commission. ${ }^{76}$ The NPB relies, just as the European framework, on competition among providers to stimulate investments and innovation. The case of the Netherlands shows clearly that competition generates large benefits, but at the same time, the outcome of the market process is unpredictable. What we see is that local conditions and cost considerations lead to a patchwork quilt, with holes, of facilities-based competition. In addition, there is a strong tendency

\footnotetext{
${ }^{74}$ Averill, Bruce and Eric A.M. Luiijf. "Canvassing the Cyber Security Landscape: Why Energy Companies Need to Pay Attention.” Journal of Energy Security (May 2010), last accessed Jan. 23, 2011, http://www.ensec.org/index.php?option=com_content\&view=article\&id=243: canvassing-the-cyber-securitylandscapewhy-energy-companies-need-to-pay-attention\&catid=106:energysecuritycontent0510\&Itemid=361. ${ }^{75}$ Schejter.

${ }^{76}$ Federal Communications Commission, Connecting America: The National Broadband Plan (Mar. 16, 2010).
} 
towards consolidation, in fixed telecommunications, mobile telecoms, and broadband Internet access.

Arguably, the implementation of local loop unbundling has been more successful in Europe than in the US. Perhaps too successful in particular cases, looking at the experience in the Netherlands, where access rates are still very low and CLECs stopped short to roll out FTTH. The best answer to this is not necessarily a continuation of unbundling and network access regulation. A greater role for the government may induce more efficiency, innovation (at the edges of the network), and options for customers in the long term. Ultimately, when the finely meshed part of the network tends towards a monopoly, we will be faced with the question of what is best: a public or private monopoly? The answer to this question depends on the extent to which a regulator can exert control over the monopolist, and on the extent to which the regulator is able to prevent the monopolist from misbehaving via the regulatory contract. The latter may be difficult if a complete contract cannot be designed.

The NBP recognizes, just as is the case in Europe, the importance of an open, vibrant Internet, and the spillovers it generates. At the same time, the more variegated nature of competition in the EU and the availability of other possibilities for taking action to combat anti-competitive behavior imply that there is possibly less reason for concern in the EU than in the $\mathrm{US} .^{77}$ In the US, one may consider to put more weight on infrastructure regulation. This is because the oligopolistic market structure will most likely not lead to effective competition among providers, especially if network bias practices lead to horizontal differentiation among networks. In particular, the regulator needs to have the necessary power to prevent anti-competitive discrimination and to safeguard transparency.

To an outsider, it seems that the policy debate in the US is relatively polarized. From across the ocean, it seems that stakeholders have a lot of influence to frame and influence the debate. For

\footnotetext{
${ }^{77}$ Filomena Chirico, Ilse M. van der Haar, and Pierre Larouche. "Network Neutrality in the EU." Discussion Paper 2007-030. TILEC, Tilburg University, Tilburg, The Netherlands (2007).
} 
instance, to an outsider from Europe it can be surprising that the view that deregulation is a precondition for investments by firms is so prominently positioned in the public debate. Such a view is an over-simplification that may easily distort the debate. Moreover, it steers the debate away from the fact that there are important public interests that the government needs to deal with. Electronic communications is too important for society, including the private sector, to be captured by vested interests of a small group of insiders. Also with respect to the challenge to connect all citizens to broadband Internet, it is unfortunate that the policy debate in the US is very polarized. Without sufficient momentum in the political process, it is hardly possible to make a big leap in broadband penetration.

The US and the EU address technological change in different ways. In the US, the implementation of communications policy has been hampered (or harmed) by technologically determined decisions. For instance, this led to deregulation of high-speed ISPs. In Europe, the regulatory framework for telecommunications (both the regulatory framework and legal procedures) is based on the notion of technological neutrality, which is the common sense way to prevent excess inertia in the development of the market. Such a notion of neutrality is a must for effective policy in a sector where technological change is extremely fast.

Overall, Europe seems to have a more effective regulatory framework. ${ }^{78}$ At the same time, the case of the Netherlands demonstrates that this does not automatically lead to the desired outcome. The European regulatory framework and its underlying policy objectives are in need of revision. However, the institutional system in the EU will, at some point, make room for the necessary policy discussions. In the US, the most important challenges are probably to safeguard the strength of the regulator and to build up the support (based on sound economic arguments) for the ambitious goals of the NBP.

\footnotetext{
${ }^{78}$ Schejter.
} 


\section{Conclusion}

Since the advent of liberalization, innovation in electronic communications has brought us tremendous benefits. At the same time, the telecom sector has not developed without some surprises along the way. Without wanting to be pessimistic, it could be argued that the market has proven to be stubborn. While it may be true that policymakers and regulators were well prepared for the task ahead and carried out sound work which has yielded significant benefits to consumers, market developments are difficult to predict or control in a market such as this one, with rapid technological developments. We underestimated this crucial aspect. Moreover, the Dutch experience illustrates the fact that regulation not only shapes the state of the market, it is also contingent on the state of the market with which it interacts. Beliefs held by a regulator may become self-fulfilling prophecies, which is worrisome is the stakes are high, as is the case with the current transition to NGNs.

What does the future hold in store? Are we actually able to supply an answer to this question which will provide us with a basis for pursuing an effective policy? One decade on, there are some important lessons that we can learn from what happened at the end of the 1990s. For example, in spite of carefully structured and soundly executed ex ante regulation, a dynamic market pays little heed to detailed transition paths leading towards a final objective. Also, we still do not know whether the roll-out of competing networks is viable in practice. Perhaps we were too optimistic with the idea that scale effects were no longer relevant in telecommunications. A further lesson we can learn is to abandon the logic that players with vested interests put forward. When using their mobiles, surfing the Internet, or downloading and sharing music, the new generation of users simply ignores the institutional environment. Music downloading and sharing takes place on a far greater scale than the statutory restrictions permit. Of course, prohibitions are prohibitions, but who knows what types of innovation, new business models, and wealth benefits might arise if we were to 
accept the new reality instead of obstructing it.

The outstanding success of the introduction of market forces in the telecom sector - in the perception of the public debate - has taken a surprising turn. Policymakers and regulators may not rule out the option of a return to a natural monopoly. Viewed from that perspective: the complex interaction between regulation and investment incentives may possibly demand other solutions than the approach of the past decade. Regulation can take a more low-key approach to the enforcement of a market design. Instead, policymakers and regulators can focus more on facilitating innovations and investments. Where these do not eventually materialize, but are nonetheless considered desirable from a welfare perspective, the government can play a more active role. This can be justified given the spill-over effects of electronic communications into other sectors of the economy; in other words, it can constitute a public interest. Another option, which can be justified in the light of other market failures, is to be less insistent on maintaining the idea of promoting competition as a goal in itself. Take, for example, the use of "regulatory holidays," stronger government control in the case of a vertical split-off of a network, and coordinating (or permitting the alignment of) investments. An example of the latter could be the coordinated laying of empty pipes on a one-off basis, followed by the auctioning off of a small number of licences for access to those pipes (and hence for fiber-optic connections through those pipes). New and challenging issues continue to present themselves. Liberalization in telecommunications: we benefit hugely from it, but the mission cannot be declared a success just yet and the operations have yet to be completed. 


\section{Bibliography}

Averill, Bruce and Eric A.M. Luiijf. "Canvassing the Cyber Security Landscape: Why Energy Companies Need to Pay Attention.” Journal of Energy Security (May 2010), last accessed Jan. 23, 2011, http://www.ensec.org/index.php?option=com_content\&view=article\&id=243: canvassing-thecyber-security-landscapewhy-energy-companies-need-to-payattention \& catid=106:energysecuritycontent $0510 \&$ Itemid $=361$.

Bijlsma, Michiel and Machiel van Dijk. "Nieuwe Generatie Netwerken, Nieuwe Generatie Regulering?" CPB Document 145, CPB, The Hague, The Netherlands (2007).

BuddeCom. "Netherlands - Telecoms, IP Networks and Digital Media." Country Report, 8th ed. (2009).

Budde, P. “The FttH versus Cable Debate Misses the Point,"BuddeBlog, July 21, 2009, last accessed Jan. 16, 2011. http://www.buddeblog.com.au/the-ftth-versus-cable-debate-misses-thepoint/.

. “Global Regulatory Re-think Required.” BuddeBlog, July 27, 2009, accessed Jan. 16, 2011. http://www.buddeblog.com.au/global-regulatory-re-think-required/.

. "National Telcos Can and Will Change Their Behaviour." BuddeBlog, Aug. 17, 2009, last accessed Jan. 16, 2011. http://www.buddeblog.com.au/national-telcos-can-and-will-changetheir-behaviour/.

Buigues, Pierre A. and Patrick Rey. The Economics of Antitrust and Regulation in

Telecommunications: Perspectives for the New Regulatory Framework. Cheltenham/ Northampton, MA: Edward Elger, 2004.

Cave, Martin. "Making the Ladder of Investment Operational." Mimeo. Warwick Business School, University of Warwick, United Kingdom (2004).

Telecommunications Policy 30, no. 3-4 (2006): 223-237.

Cave, Martin and Keiko Hatta. "Transforming Telecommunications Technologies - Policy and Regulation." Oxford Review of Economic Policy 25, no. 3 (2009): 1-18.

Chirico, Filomena, Ilse M. van der Haar, and Pierre Larouche. "Network Neutrality in the EU." Discussion Paper 2007-030. TILEC, Tilburg University, Tilburg, The Netherlands (2007). CPB. "Competition in Communication and Information Services: Opportunities and Obstacles." Bijzondere Publicatie 12, The Hague, The Netherlands (1997).

De Bijl, Paul W.J. "Structural Separation and Access in Telecommunications Markets.” Journal of Network Industries 6, no. 2 (2005): 95-114. 
. "Liberalisering in Telecom: Missie Geslaagd, Operatie Afgerond?" In Preadviezen 2009: Marktwerking en Publieke Belangen, edited by Eric van Damme and Maarten Pieter Schinkel, 117-146. Amsterdam: KVS (Royal Netherlands Economic Association), 2009.

. "The Need for a Communications Regulator: A Lesson from the Netherlands."

Mimeo. CPB, The Hague, The Netherlands (2010).

De Bijl, Paul W.J. and Martin Peitz. Regulation and Entry into Telecommunications Markets.

Cambridge, Cambridge University Press, 2002.

. "Local Loop Unbundling in Europe: Experience, Prospects and Policy

Challenges." Communications \& Strategies 57, no. 1 (2005): 33-57.

. "Innovation, Convergence and the Role of Regulation in the Netherlands and

Beyond." Telecommunications Policy 32, no. 11 (2008): 744-754.

De Bruijn, Hans and Willemijn Dicke. "Strategies for Safeguarding Public Values in Liberalized

Utility Sectors.” Public Administration 84, no. 3 (2006): 717-735.

Economides, Nicholas. "The Economics of the Internet." In The New Palgrave Dictionary of

Economics, 2nd Ed. London: Macmillan, 2007.

. "Why Imposing New Tolls on Third-Party Content and Applications

Threatens Innovation and Will Not Improve Broadband Providers' Investment.” Working Paper \#10-01, NET Institute (2010).

“Elektronische communicatie en media: omroepdistributie en inrichting toezicht." Letter, Mar. 10, 2009, ref. ET/EM/9038511.

European Commission. 14th Report on the Implementation of the Telecommunications Regulatory

Package - 2008. Last accessed Jan. 16, 2011,

http://ec.europa.eu/information_society/policy/ecomm/library/communications_reports/annualre ports/14th/index_en.htm.

European Community. Directive 2002/19/EC of the European Parliament and of the Council of 7 March 2002 on Access to, and Interconnection of, Electronic Communications Networks and Associated Facilities (Access Directive) (Official Journal of the European Communities, 24 April 2002, art. 11, p. L 108/110).

Regulation (EC) No. 2887/2000 of the European Parliament and of the

Council of 18 December 2000 on Unbundled Access to the Local Loop (Official Journal of the European Communities, 30 December 2000, art. 11, p. L 336/5).

Federal Communications Commission. Connecting America: The National Broadband Plan (Mar. $16,2010)$.

Frieden, Rob M. “Network Neutrality and its Potential Impact on Next Generation Networks.” In The Selected Works of Rob Frieden. Mimeo. Pennsylvania State University. 2007. 
“FTTH in The Netherlands 2010 Q1.” Stratix Consulting, Hilversum, The Netherlands (2010).

Grajek, Michal and Lars-Hendrik Röller. "Regulation and Investment in Network Industries:

Evidence from European Telecoms.” Working Paper No. 09-004, European School of Management and Technology (ESMT), Berlin, Germany (2009).

Hogendorn, Christiaan. "Spillovers and Network Neutrality." In Regulation and the Performance of Communication and Information Networks, edited by Gerald Faulhaber, Gary Madden, and Jeffrey Petchey. Edward Elgar, forthcoming.

Huigen, Jos and Martin Cave. "Regulation and the Promotion of Investment in Next Generation Networks - A European Dilemma.” Telecommunications Policy 3, no. 11 (2008): 713-721. Janssen, Maarten C.W. and Ewa Mendys-Kamphorst. "Triple play: How Do We Secure the Benefits?" Telecommunications Policy 32, no. 11 (2008): 735-743.

Knieps, Günter. "Telecommunications Markets in the Stranglehold of EU Regulation: On the Need for a Disaggregated Regulatory Contract." Journal of Network Industries 6, no. 2 (2005): 75-93. Kocsis, Viktoria and Paul W.J. de Bijl. "Network Neutrality and the Nature of Competition between Network Operators.” International Economics and Economic Policy no. 4 (2007): 159-184.

Lavey, Warren G. "Telecom Globalization and Deregulation Encounter U.S. National Security and Labor Concerns.” Journal on Telecommunications and High Technology no. 6 (2007): 121-178.

LECG, "Access regulation and infrastructure investment in the telecommunications sector: An empirical investigation”, Londen (2007).

Lemstra, Wolter. "Do We Need Policy 3.0 for Telecom 3.0? The Case of the Netherlands." Mimeo. Technical University Delft, Dept. of Technology, Policy \& Management, Delft, The Netherlands (2009).

Ministry of Economic Affairs. "Effecten Marktwerkingsbeleid.” The Hague, The Netherlands (2008).

Nederlandse Mededingingsautoriteit, Besluit nr. 6397 / 274, “6397/KPN - Reggefiber”, July 28, 2009.

"New National Broadband Network", media release April 7, 2009, last accessed Jan. 23, 2011, http://www.minister.dbcde.gov.au/media/media_releases/2009/022.

Noam, Eli. "Fundamental Instability: Why Telecom is Becoming a Cyclical and Oligopolistic Industry." Information Economics and Policy 18, no. 3 (2006): 272-284. . "Regulation 3.0 for Telecom 3.0." Telecommunications Policy 34, no. 1-2 (2010): 4-10.

Odlyzko, Andrew. “Telecom dogmas and spectrum allocations.” Mimeo. Digital Technology Center, University of Minnesota, Minnesota (2004).

OECD Broadband Portal. Last accessed Jan. 16, 2011, http://www.oecd.org/sti/ict/broadband. OECD. "Network Developments in Support of Innovation and User Needs." Working Party on 
Communication Infrastructures and Services Policy. DSTI/ICCP/CISP(2009)2/FINAL (2009).

OPTA. “Is Two Enough?” Economic Policy Note no. 6. The Hague, The Netherlands (2006).

“OPTA start per direct nieuw onderzoek televisiemarkt - Uitspraak CBb biedt geen ruimte voor snelle openstelling tv-kabel.” Press Release, OPTA, Aug. 31, 2010, last accessed Jan. 16, 2011. http://www.broadbandtvnews.com/2010/08/18/court-overturns-optas-open-cable-ruling/.

"Richtsnoeren met betrekking tot ontbundelde toegang tot de aansluitlijn ('MDF-access')." OPTA, March 16, 1999/OPTA/J/99/1443.

“Ruim baan snel Internet gemeenten.” Het Financieele Dagblad, Sept. 9, 2009.

Schejter, Amit M. “'From All My Teachers I Have Grown Wise, and From My Students More than Anyone Else': What Lessons Can the US Learn from Broadband Policies in Europe?" International Communication Gazette 71, no. 5 (2009): 429-445.

“Tele2 Buys bbned.” Light Reading Europe, July 16, 2010, last accessed Jan. 16, 2011. http://www.lightreading.com/document.asp?doc_id=194484.

“Tribunal Overturns OPTA’s Open Cable Ruling.” Broadband TV News, Aug. 18, 2010, last accessed Jan. 16, 2011.

http://www.broadbandtvnews.com/2010/08/18/court-overturns-optas-open-cable-ruling/.

Van Damme, Eric E.C. “Competition in the Local Loop." Visions, study, VECAI, The Hague, The Netherlands (1999).

"Vodafone Netherlands, Eurofiber Partner on Business Fiber." Telecompaper, Sept. 1, 2010, last accessed Sept. 13, 2010. http://www.telecompaper.com/news/article.aspx?cid=754180.

“Telefonie via kabel in Amsterdam." Computable, January 16, 1997, accessed on January 23, 2011, http://www.computable.nl/artikel/nieuws/211001/250449/telefonie-via-kabel-inamsterdam.html.

“Upgrade kabelnet bedreigt uitrol glasvezel KPN." Webwereld, April 22, 2009, last accessed Jan. $23,2011$.

http://webwereld.nl/nieuws/57208/upgrade-kabelnet-bedreigt-uitrol-glasvezelkpn.html\#source=head.

“Meeste klachten over sms en slamming." ZDNet, May 19, 2009, last accessed Jan. 23, 2011. http://www.zdnet.nl/news/102651/meeste-klachten-over-sms-en-slamming-/ 

Publisher:

CPB Netherlands Bureau for Economic Policy Analysis

P.O. Box $80510 \mid 2508$ GM The Hague

$\mathrm{T}(070) 3383380$

March 2011 | ISBN 978-90-5833-496-1 